\title{
Abomasal Nematodes in Goats Slaughtered at Different Abattoir of Thakurgaon District, Bangladesh
}

\author{
M. Nuruzzaman ${ }^{1}$, M. H. Haque ${ }^{2}$, S. Sarker ${ }^{2 *}$ and N. Begum ${ }^{1}$ \\ ${ }^{1}$ Department of Parasitology, Bangladesh Agricultural University, Mymensingh-2202, Bangladesh \\ ${ }^{2}$ Department of Animal Husbandry and Veterinary Science, Faculty of Agriculture, University of \\ Rajshahi, Rajshahi-6205, Bangladesh
}

Receive 17 April 2011, accepted in final revised form 6 February 2012

\begin{abstract}
A study was carried out to estimate the prevalence, species composition and worm burden of abomasal nematodes of goats slaughtered at different abattoir of Thakurgaon district from November 2009 to April 2010. During the study period, 250 abomasum of goats were examined according to standard procedures. Two species of nematodes were identified in goats abomasum with an overall prevalence of $74.00 \%(n=250)$. The specific prevalence rate for Haemonchus contortus (58.00\%) was higher than Trichostrongylus axie (16.00\%). In this study, prevalence of abomasal nematodes in relation to age, sex, breed and nutritional status of the goats were also observed. There was no statistically significant difference observed the risk factor sex in relation to the prevalence of abomasal nematodes. However, there was statistically significant difference $(p<.001)$ observed among the risk factors (age, breed and nutritional status) in relation to the prevalence and worm count of two abomasal nematodes. In general, a high infection rate with abomasal nematodes was observed in goats during the study period. Findings suggested that higher worm burden per animal found in Haemochus contortus (6.02 \pm 0.0928$)$ and lower in Trichostrongylus axie $(0.04 \pm 0.14)$. From this study it was concluded that Haemochus contortus is more susceptible for geo-climatic condition in research area.
\end{abstract}

Keywords: Abomasal nematodes; Prevalence; Goats; Thakurgaon.

(c) 2012 JSR Publications. ISSN: 2070-0237 (Print); 2070-0245 (Online). All rights reserved.

doi: http://dx.doi.org/10.3329/jsr.v4i2.7475 J. Sci. Res. 4 (2), 491-497 (2012)

\section{Introduction}

Livestock production is an important sector of the Bangladesh agricultural economy, providing a significant contribution to gross domestic and export products and raw materials for industries. Goats rank second in position in terms of meat and skin production representing about $38 \%$ and $28 \%$ respectively of the total livestock in Bangladesh [1]. The total goat population in Bangladesh was 1.75 cores, among them

* Corresponding author: sarkersubir@yahoo.com 
about 1.85 million in Thakurgaon district [2]. About 70-80\% of the goats here are reared in the riverside area. Parasitism is claimed to be one of the main obstacles in livestock rearing in Bangladesh [3]. The agro-ecological and geo-climatic conditions of Bangladesh are highly favourable for growth and multiplication of parasitic diseases in goat [4].

Among the diseases of goats, the parasitic diseases are of prime importance in Bangladesh. According to Rahman et at. [5], 25\% kids and 43\% adult goats die of gastrointestinal parasitism under both rural and farm condition. In addition to mortality, morbidity due to parasitism is also considered very high due to insidious effects of parasitic infestation in ill health and productivity [6]. Of the parasites, stomach worms are responsible for burden of goat population in comparison with other ruminants [7]. Among the parasitic diseases the stomach worm especially the blood sucking Haemonchus contortus causes serious economic losses. It causes a loss of 0.05-0.07 ml blood/parasite/day, stunted growth, weight loss, decreased meat and milk production, anaemia, and finally leads to death of goats $[6,8]$.

The control of abomasal nematodes infection of livestock in Bangladesh is based on the use of anthelmintics. Pasture management is either unknown or not practiced by smallholder farmers. Due to high cost of drugs farmers do not deworm regularly but rather treat selectively according to clinical signs [9]. Due to this underlined fact there is high prevalence of the disease. Therefore, this study was undertaken with the objectives to determine the prevalence and load of abomasal nematodes in goats slaughtered in Thakurgaon district, and to determine the relationship between the risk factors like age, sex, breed and nutritional status and the prevalence and to look at the burden (intensity) of abomasal nematodes in goats.

\section{Materials and Methods}

\subsection{Study area}

The research work was conducted in Thakurgaon district from November 2009 to April 2010. A total of 31 abattoirs were selected randomly in the urban areas of Thakurgaon district. Most of the abattoirs were made by aluminum tin with concrete floor and some were mud-spattered floor.

\subsection{Study animals and sampling method}

The study was conducted on goats slaughtered in 31 abattoirs in the urban areas of Thakurgaon district. A total of 250 abomasums from slaughtered goats were examined. Most of the samples were obtained from different abattoirs and it was difficult to trace the exact origin of the animals. The age of the animal was estimated by examination of the teeth and separated into two age group like young ( $\leq 20$ months) and adult $\ell 20$ months) for abomasal sample. In order to undertake the postmortem examination, the abomasums were legated with string and collected from different abattoir. 


\subsection{Worm recovery}

The laboratory work was done at parasitiology laboratory of the Department of Parasitology, Bangladesh Agricultural University, Mymensingh. The parasitic collections of the abomasal contents and washings were made after the method adopted by authors $[10,11,5]$. Detailed morphological features of the parasites and eggs were studied after they were cleared in order to identify the species [5]. Preliminary morphological studies of the parasites were made in living conditions taking representative samples from each collection.

\subsection{Species identification}

The worms which were preserved in $10 \%$ formalin were poured in to petridishes and examined under a stereomicroscope. Identification was made using keys developed by [12] and [13].

\subsection{Data analysis}

Statistical analyses were carried out with Statistical Package for Social Sciences (SPSS) using F test. Odds ratio was calculated by standard formula [14].

\section{Results and Discussions}

In this investigation, a total of 250 abomasums of goats were examined and revealed the presence of two different species of nematodes with overall prevalence rates of $74.00 \%$. The specific prevalence of the two species of nematodes identified were, Haemonchus contortus $58.00 \%$ Trichostrongylus axie $16.00 \%$ indicated in (Table 1). From this study, it was observed that the prevalence of Haemonchus contortus was higher than Trichostrongylus axie which is in agreement with the findings of previous studies [15, $16]$. Conversely, the finding of this study was slightly higher than the prevalence of $61.80 \%$ reported in Hawassa [17]. Overall, worm burden of Haemochus contortus (6.02) was higher than Trichostrongylus axie (0.04) per animal.

Table 1. Overall prevalence of abomasal nematodes in goats.

\begin{tabular}{lcccc}
\hline Name of stomach worm & $\begin{array}{c}\text { No. of goats affected } \\
(\mathrm{n}=250)\end{array}$ & $\begin{array}{c}\text { Prevalence } \\
(\%)\end{array}$ & \multicolumn{2}{c}{ Worm burden } \\
& 145 & 58 & $0-21$ & $6.20 \pm 0.928$ \\
\hline Haemonchus contortus & 40 & 16 & $0-04$ & $0.40 \pm 0.14$ \\
Trichostrongylus axie & 185 & 74 & $0-21$ & $3.30 \pm 0.534$ \\
Total & & & & \\
\hline
\end{tabular}




\subsection{Prevalence based on age}

Age can affect the occurrence of parasites. However, prevalence of abomasal nematodes in goats were significantly $(p<0.01$ ) higher in young aged $(84.61 \%)$ than adult aged (61.21\%). Youngs were 3.30 times more susceptible than adults (Table 2). The study found that the prevalence decreased as the age increased. This is in agreement with the research done by authors $[18,19]$. Even though the reasons underlying age resistance are not well known, the possible explanation of this may be that the development of acquired immunity and immune-competence increase as the age increases due to high rate of exposure to parasitic infestations [18]. Young animals are highly susceptible due to immunological immaturity and immunological unresponsiveness [19]. Young goats were examined for adult parasitic worm burden, 90 (69.23\%) goats harbored adult worms of Haemonchus contortus with mean count of 6.46 per animal and 20 (15.38\%) had Trichostrongylus axie with mean count of 0.31 per animal. In adult goats, 55 (45.83\%) were lightly infected with $H$. contortus and 20 (16.66\%) were moderately infected with $T$. axie. The results of overall worm count and specific counts for the two abomasal nematodes were higher in young than adult goats. This finding was in conformity with previous studies [20,15].

Table 2. Prevalence of abomasal nematodes in different age group of goats.

\begin{tabular}{|c|c|c|c|c|c|c|}
\hline \multirow[t]{2}{*}{ Age of goat } & \multirow{2}{*}{$\begin{array}{c}\text { Name of stomach } \\
\text { worm }\end{array}$} & \multirow{2}{*}{$\begin{array}{l}\text { No. of goats } \\
\text { affected }\end{array}$} & \multirow{2}{*}{$\begin{array}{c}\text { Prevalence } \\
\text { (\%) }\end{array}$} & \multicolumn{2}{|c|}{ Worm burden } & \multirow{2}{*}{$\begin{array}{l}\text { Odd } \\
\text { ratio }\end{array}$} \\
\hline & & & & Range & Mean \pm SE & \\
\hline $\begin{array}{c}\text { Young } \\
(<20 \text { months })\end{array}$ & $\begin{array}{l}\text { Haemonchus } \\
\text { contortus }\end{array}$ & 90 & 69.23 & $0-18$ & $6.46 \pm 1.13$ & Young \\
\hline \multirow[t]{2}{*}{$N=130$} & Trichostrongylus axie & 20 & 15.38 & $0-3$ & $0.31 \pm 0.15$ & Adult \\
\hline & Sub total & 110 & 84.61 & $0-18$ & $3.38 \pm 0.075$ & $=3.3$ \\
\hline $\begin{array}{c}\text { Adult } \\
(\geq 20 \text { months })\end{array}$ & $\begin{array}{l}\text { Haemonchus } \\
\text { contortus }\end{array}$ & 55 & 45.83 & $0-21$ & $5.92 \pm 1.51$ & \\
\hline \multirow[t]{3}{*}{$N=120$} & Trichostrongylus axie & 20 & 16.66 & $0-4$ & $0.50 \pm 0.24$ & \\
\hline & Sub total & 75 & 61.21 & $0-21$ & $3.35 \pm 0.88$ & \\
\hline & $P$ value & & & & $0.0013^{*}$ & \\
\hline
\end{tabular}

$* p<0.01$.

\subsection{Association of prevalence with sexes of goats}

There was no statistically significant association between sex and prevalence of abomasal nematodes in goats (Table 3). The results showed that the prevalence of abomasal nematodes was almost similar in females $(74.07 \%)$ and male $(73.91 \%)$ goats (odd ratio 1.008). Prevalence of $H$. contortus was higher in male (65.22\%) with mean count of 7.00 per animal than female (51.58\%) with mean count of 5.52 per animal but $T$. axie was higher in male (22.22\%) than female (8.69\%). This result is in agreement with the finding in Bangladesh [21] and Nigeria [22] who observed that prevalence was not related to sex. 
Table 3. Prevalence of abomasal nematodes in both sexes of goats.

\begin{tabular}{clccccc}
\hline $\begin{array}{c}\text { Sex of } \\
\text { goat }\end{array}$ & Name of stomach worm & $\begin{array}{c}\text { No. of } \\
\text { goats } \\
\text { affected }\end{array}$ & $\begin{array}{c}\text { Prevalence } \\
(\%)\end{array}$ & $\begin{array}{c}\text { Worm burden } \\
\text { Range }\end{array}$ & Mean \pm SE & Odd ratio \\
\hline Female & Haemonchus contortus & 70 & 51.85 & $0-21$ & $5.52 \pm 1.26$ & Female vs \\
$(n=135)$ & Trichostrongylus axie & 30 & 22.22 & $0-4$ & $0.56 \pm 0.22$ & Male \\
& Sub total & 100 & 74.07 & $0-21$ & $3.04 \pm 0.24$ & $=1.008$ \\
Male & Haemonchus contortus & 75 & 65.22 & $0-18$ & $7.00 \pm 1.37$ & \\
$(n=115)$ & Trichostrongylus axie & 10 & 8.69 & $0-3$ & $0.22 \pm 0.15$ & \\
& Sub total & 85 & 73.91 & $0-18$ & $3.61 \pm 0.76$ & \\
& $P$ value & & & & $0.432 \mathrm{NS}$ & \\
\hline
\end{tabular}

NS $=$ Nonsignificant

\subsection{Prevalence based on breed category}

The susceptibility of various breeds of goats to abomasal nematodes is shown in Table 4. In the present investigation, however a significant $(p<0.02)$ variation in breed susceptibility was observed affecting mostly Jamunapari goats (85.71\%) compared to Black Bengal goats (72.08\%) which is in agreement with another report [23]. Concerning breed, the parasitic worm burden of $57.14 \%$ Jamunapari goat harbored adult worms of Haemonchus contortus with mean count of 5.14 per animal which was higher than the parasitic worm burden of 55.81\% Black Bengal goat. Trichostrongylus axie was also higher in Jamunapari goat (28.57\%) than Black Bengal goat (16.27\%). Although the exact cause of higher prevalence in both Black Bengal and Jamunapari goat cannot be explained but it may be associated with genetic and inheritable effect and to some extent management factors like grazing habit, rearing system etc.

Table 4. Prevalence of abomasal nematodes in different breeds of goats.

\begin{tabular}{|c|c|c|c|c|c|c|}
\hline \multirow[t]{2}{*}{ Breed of goat } & \multirow[t]{2}{*}{ Name of stomach worm } & \multirow{2}{*}{$\begin{array}{l}\text { No. of } \\
\text { goats } \\
\text { affected }\end{array}$} & \multirow{2}{*}{$\begin{array}{c}\text { Prevalence } \\
\text { (\%) }\end{array}$} & \multicolumn{2}{|c|}{ Worm burden } & \multirow[t]{2}{*}{ Odd ratio } \\
\hline & & & & Range & Mean \pm SE & \\
\hline \multirow{3}{*}{$\begin{array}{l}\text { Black Bengal } \\
\qquad(n=215)\end{array}$} & Haemonchus contortus & 120 & 55.81 & $0-21$ & $6.37 \pm 1.02$ & \multirow{7}{*}{$\begin{array}{c}\text { Jamunapari } \\
\text { vs } \\
\text { Black } \\
\text { Bengal } \\
=2.32\end{array}$} \\
\hline & Trichostrongylus axie & 35 & 16.27 & $0-04$ & $0.42 \pm 0.15$ & \\
\hline & Sub total & 155 & 72.08 & $0-21$ & $3.39 \pm 0.09$ & \\
\hline \multirow{4}{*}{$\begin{array}{c}\text { Jamunapari } \\
\quad(n=35)\end{array}$} & Haemonchus contortus & 20 & 57.14 & $0-16$ & $5.14 \pm 2.23$ & \\
\hline & Trichostrongylus axie & 10 & 28.57 & $0-02$ & $0.29 \pm 0.28$ & \\
\hline & Sub total & 30 & 85.71 & $0-16$ & $2.72 \pm 1.26$ & \\
\hline & $P$ value & & & & $0.0002 *$ & \\
\hline
\end{tabular}

$n=$ total animal examined; $* p<0.01$ 


\subsection{Association of prevalence with nutritional status of goats}

The study revealed that nutritional status of the goat had significant $(p<0.01)$ effect on abomasal nematodes infection. The prevalence of stomach worms was higher in poor body conditioned goat (93.75\%) than normal body conditioned goat (67.63\%) (Table 5). Poor body conditioned goats were 7.17 times more susceptible than normal body conditioned goats. In normal body conditoned goat, the prevalence of $H$. contortus (47.05\%) was higher than T. axie (20.58\%). On the other hand, in poor body conditioned goat, the prevalence of $H$. contortus (81.25\%) was also higher than $T$. axie (12.50\%). The worm burden per animal was also significantly $(p<0.01)$ higher in poor body conditioned goats (7.04) than normal body conditioned goats (1.55) which agrees with an arlier study [24] who reported that in immisunocompromised animal, fecundity of parasites is usually increased.

Table 5. Association between prevalence of abomasal nematodes and nutritional status of goats.

\begin{tabular}{clccccc}
\hline $\begin{array}{c}\text { Nutritional } \\
\text { status of goat }\end{array}$ & $\begin{array}{c}\text { Name of stomach } \\
\text { worm }\end{array}$ & $\begin{array}{c}\text { No. of } \\
\text { goats } \\
\text { affected }\end{array}$ & $\begin{array}{c}\text { Prevalence } \\
\text { (\%) }\end{array}$ & \multicolumn{2}{c}{$\begin{array}{c}\text { Worm burden } \\
\text { Range }\end{array}$} & Odd ratio \\
\hline $\begin{array}{c}\text { Normal body } \\
\text { condition }\end{array}$ & $\begin{array}{l}\text { Haemonchus } \\
\text { contortus }\end{array}$ & 80 & 47.05 & $0-11$ & $2.56 \pm 0.60$ & $\begin{array}{c}\text { Poor } \\
\text { body }\end{array}$ \\
$n=170$ & $\begin{array}{l}\text { Trichostrongylus axie } \\
\end{array}$ & 35 & 20.58 & $0-04$ & $0.53 \pm 0.195$ & vs \\
Sub total & 115 & 67.63 & $0-11$ & $1.55 \pm 0.39$ & Normal \\
$\begin{array}{c}\text { Condition body } \\
n=80\end{array}$ & $\begin{array}{l}\text { Haemonchus } \\
\text { contortus }\end{array}$ & 65 & 81.25 & $6-21$ & $13.94 \pm 1.10$ & body \\
& Trichostrongylus axie & 10 & 12.50 & $0-21$ & $0.13 \pm 0.125$ & $=7.17$ \\
& Sub total & 75 & 93.75 & $0-21$ & $7.04 \pm 0.612$ & \\
& $P$ value & & & & $0.001 *$ & \\
\hline
\end{tabular}

$n=$ total animal examined; $* p<0.01$.

\section{Conclusion}

Nematodiosis is one of the major obstacles to livestock productivity in Bangladesh. Its occurrence is mainly associated with the poor management system, lack of disease resistance breed selection and development of drug resistance of the parasite. Observation from the present study conducted on abomasal nematodes in goats, and goats slaughtered in different abattoirs showed that nematode in goats is the most prevalent disease in the area affecting the health of the animals. The species of parasites identified were Haemonchus contortus and Trichostrongylus axie. Therefore, significant economical losses in production are expected to occur in the study area. 


\section{Acknowledgements}

The researchers would like to extend the gratitude to Veterinary Parasitology laboratory under the Department of Parasitology, Bangladesh Agricultural University, Mymnesingh for its technical and material support in the realization of this study.

\section{References}

1. FAO, Production Year Book 51, 189 (1997).

2. BBS, Statistical Pocket Book of Bangladesh. (Statistics Division, Ministry of Planning, Dhaka, Bangladesh, 2009).

3. Jabbar and D. A. G. Green, The status and potential of livestock within the context of agricultural development policy in Bangladesh, The University of Wales (Aberyswyth, UK, 1983) p.113.

4. S. Haq and H. Shaikh, East Pak. J. Vet. Sci. 2, 54 (1968).

5. M. H. Rahman, K. N. Soliman, and H. Shaikh, Proceedings of Pakistan Scientific Conference, University of Peahwar 17, (1975).

6. E. J. L. Soulsby, Helminths, Arthropods and Protozoa of Domesticated Animals, $6^{\text {th }}$ ed. Bailliere (Tindall, London, 1968).

7. A. Eslami and A. Faizy, J. Vet. Faculty of Tehran University 31, 73 (1976).

8. M. A. Samad, Poshu Palan O Chikitsavidya, $2^{\text {nd }}$ ed. (LEP Publication, No. 08. BAU Campus, Mymensingh) (2001).

9. F. R. Chaudary, M. F. U. Khan, and M. Qayyum, Pak. Vet. J. 27 (2), 73 (2007).

10. E. L. Taylor, Animal Trop. Med. Parasites 19 (1), 57 (1934).

11. E. A. Bell, Can. J. Zool. 35, 163 (1957). http://dx.doi.org/10.1139/z57-011

12. J. Hansen and B. Perry, The Epidemiology, Diagnosis and Control of Helminth Parasites of Ruminants. International Livestock Center for Africa, Addis Ababa (Ethiopia, 1994) p. 90.

13. MAFF (Ministry of Agriculture, Fisheries and Food), Manual of Veterinary Parasitological Laboratory Techniques (Her Majesty Stationary Office, London, 1986).

14. Schlesselman, Case-control Studies: Design, Conduct, Analysis (New York: Oxford U. Press, 1982) p. 144.

15. T. Naod, S. Teshale, and K. Bersissa, Thesis, FVM (AAU, 2006).

16. B. Kumsa and A. Wossene, Revue de Medecine Veterinaire 157 (12), 27 (2006).

17. M. Bitew, Y. Amde, and K. Belachew, Veterinary Research 4 (2), 39 (2011). http://www.medwelljournals.com/ref.php?doi=vr.2011.39.44

18. G. M. Urquhart, J. Armour, J. L. Duncon, A. M. Dunn, and F. W. Jennings, Veterinary Parasitology (Longman Scientific and Techenical Press, UK, 1998) p. 3.

19. M. F. Asanji and M. O. Williams, Bull. Animal Health and Production in Africa 35, 308 (1987).

20. T. Fritsche, J. Kaufmann, and K. Pfister, Veterinary Parasitology 49, 271 (1993). http://dx.doi.org/10.1016/0304-4017(93)90126-8

21. M. A. Shahadat, M. J. Karim, M. Z. Alam, and S. Majumder, Bangladesh Veterinarian 20 (1), 72 (2003).

22. F. C. Okafor, G. Mbata, and J. Anosike, Bull. Animal Health and production in Africa 38(2), 142 (1988).

23. A. N. M. A. Qadir, Bang. Vet. J. 15, 11 (1969).

24. E. Etter, C. Chartier, H. Hoste, and L. P. Borgida, Revue de medicine Veterinaire 150 (12), 975 (1999). 